\title{
Characterization of buffalo milk production system in Bangladesh
}

\author{
MK Uddin ${ }^{1}$, AA Mintoo' ${ }^{1}$, TM Awal ${ }^{1}$, M Kondo ${ }^{2}$, AKMA Kabir ${ }^{3 *}$ \\ ${ }^{1}$ Lal Teer Livestock Limited, Anchor Tower, Dhaka, Bangladesh, ${ }^{2}$ Faculty of Bioresources, Mie University, Japan, \\ ${ }^{3}$ Department of Animal Science, Bangladesh Agricultural University, Mymensingh-2202, Bangladesh
}

\begin{abstract}
This survey study was conducted in Tangail, Jamalpur, Bogra, Sirajganj, Pabna and Thakurgaon districts for household farming, and in Bhola, Noakhali, Lakshmipur and Patuakhali districts for bathan farming to undertake an assessment on the management factors in household and bathan farming for identifying the potentiality and constraints in milk production from buffalo. A 90 number of pre-designed questionnaire was used for data collection by direct interviewing of buffalo farmers. From this study, it was revealed that $82 \%$ of the farmers have 1 to 3 buffalo per household and $73 \%$ of the farmers have 51 to 200 buffalo per bathan. Buffaloes were raised in homestead and approximately 5-7 hours were grazes per day in household farming. Small quantity of concentrate feeds were offered to buffalo by the rich farmers during dry season. On the other hand, in bathan, farmers were fully depended to feed the buffalo on grazing at public land. In household, the average daily milk production was 3 to 8 liters and total milk yield was 799 liters in a lactation length of 270 days. In bathan, the average daily milk production was 1 to 2 liters and total milk yield was 435 liters in a lactation length of 215 days. The average age of first calving, service per conception, gestation period and calving interval were 39 months, 1.9 numbers, 310 days and 490 days, respectively in household farming. The average age of first calving, service per conception, gestation period and calving interval were 40 months, 2.1 numbers, 315 days and 530 days, respectively in bathan farming; however, further study is required on the buffalo nutrition in the bathan farming.
\end{abstract}

Key words: Buffalo farming system, buffalo management system, buffalo milk, Bangladesh

Bangladesh Animal Husbandry Association. All rights reserved.

Bang. J. Anim. Sci. 2016. 45 (1):69-77

\section{Introduction}

Rapid economic growth, technological innovation, management technique, improvement in feed supplies, rise in income, urbanization, climate change, effect of environment, pattern of cultivation and pattern of food habits etc. brought about a lot of changes in Asia in the livestock sector (FAO 2009). These changes have implications for the ability of the livestock sector to expand the production sustainably in ways that promote food security, poverty reduction and public health. In Bangladesh, recent studies and reports also reveal the rapid growth of human population (approximately $1.6 \%$ per annum) with urbanization (10\%, 1990-2010) (PPRC, 2011). Simultaneously growing population, poverty reduction, increase in middle class, and their increased income have changed their food preferences. These recent developments have major impacts on demand for animal derived products such as milk, meat, butter, cheese, icecream, baby foods, locally made sweets which are heavily dependent on the availability of milk. While the consumption per capita of livestock products is much higher in developed countries, substantial growth has also occurred in developing countries of Asia except Bangladesh (FAO, 2009).

In Bangladesh about $20 \%$ of the people fully and $75 \%$ of the rural people in Bangladesh rely on livestock to some extent of their livelihood (BBS, 2008). In Bangladesh, the total number of buffalo is estimated at 1.26 million $(5.21 \%$ of Bovine animal) out of which $78 \%$ is adult and $22 \%$ is young stock (BBS, 2008 and Huque et al., 2010). Within the adult buffalo, adult male and female were $58 \%$ and $33 \%$, respectively, and, within the female, milking and dry buffalo were $27 \%$ and $37 \%$, respectively (BBS, 2008). Domestic water buffaloes play an important role in providing milk, meat and draught power (Ghaffar et al., 1991).

\section{*Corresponding Author: ahsankabiras@bau.edu.bd}




\section{Buffalo milk production in Bangladesh}

Unfortunately, there is no organized buffalo improvement program until now in the country. There is no specific high yielding variety of buffalo but three distinct types, i.e., reverine, swamp and their crossbreds are found.

Traditionally, Bangladeshi people are used to depend mostly on cow milk which is highly insufficient (about $20 \%$ of demand is met with current production and rest $80 \%$ fed by imported milk at a high cost). Whereas, demand for milk is rising fast with buying capacity of the consumers and commercial users making sweets and confectionary items, the demand supply gap is also growing in an alarming rate. To minimize this gap, there is phenomenal potential opportunity to promote milk production through intensive buffalo production both in intensive household (stall feeding system) and commercial farming in the coastal area.

The average global growth of protein consumption is $0.8 \%$, in developed countries $0.2 \%$, in developing countries $1.5 \%$, and in Bangladesh $-0.4 \%$ of livestock products (SAARC, 2009). The total volume of World's buffalo milk was recorded 89.2 million tons in 2008 whereas Asian buffalo milk production represents $96.78 \%$ of total buffalo milk production (FAO, 2010). Buffaloes are significant sources of milk in this sub-region contributing as high as $68.35 \%$ of the total milk yield in Pakistan, and $56.85 \%$ in total milk production in India. Whereas in Bangladesh buffalo milk contributes less than $3.0 \%$ of total milk production (Estimated). In Bangladesh, daily average milk consumption is $40 \mathrm{ml} /$ head against required daily allowance of FAO recommendation $250 \mathrm{ml} /$ head with a deficiency of $210 \mathrm{ml} /$ head as compared to India where consumption per capita is $245 \mathrm{gm}$ against required allowance $250 \mathrm{ml}$ (Kumar \& Singh, 2010). The huge gaps are found in demand and supply of milk in Bangladesh. The objective of this study is to assess the management factors in household and bathan farming for identifying the potentiality and constraints in milk production from buffalo.

\section{Materials and methods}

The survey was conducted from two classes of buffalo farmers based on farming system namely (a) household farmers in non-saline zone and, (b) bathan farmers in costal saline zone. A total of 90 farmers from two different classes of which 54 farmers of household farming in non-saline zone from six selected districts (Tangail, Jamalpur, Bogra, Sirajganj, Pabna and Thakurgaon) and 36 farmers of bathan farming in coastal saline zone from four districts (Bhola, Noakhali, Lakshmipur and Patuakhali) of Bangladesh were selected. From the listed farm recorded at each District Livestock Officer (DLO) office, farmers were randomly selected based on the number of buffaloes per farm and on the experience of buffalo farming for face to face interview using prescribed questionnaire.

Data were collected directly from household and bathan visited by the qualified enumerators through face to face interviews. In some cases, a discussion was also conducted with the animal workers (hired labours) which were relevant to the animal workers, to confirm and recheck the information that collected from the farmers.

\section{Data Analysis}

All data were computed by Microsoft (MS) Excel program and analyzed in two factorial designs by using MS Excel STAT program.

\section{Results}

\section{Characteristics of the farmers}

The characteristics of the farmers belonging to the household and bathan farming were presented in Table 1 . There was a broad age range between two classes of farmers. In the household farming, about one-third of the total farmers were above 55 years old while there was no managed above 55 years old involved in bathan farming. The farmers aged between 35 to 54 years were in higher concentration $(79 \%)$ in bathan farming. Considering the sex, the vast majority of the farmers were male in both household and bathan farming (90 and 99\%, respectively).

However, in household farming, 65\% farmers' family size was more than five, $63 \%$ farmers was educated at least primary level and $75 \%$ farmers' occupation was only agriculture while in case of of bathan farming, $65 \%$ farmers' family size was less than five, $79 \%$ farmers was educated at least primary level and $63 \%$ farmers' were also 
involved in service and business as well along with agriculture (Table 1 ).

Table 1. Characteristics of the farmers

\begin{tabular}{cll}
\hline \multirow{2}{*}{ Parameters } & \multicolumn{2}{l}{$\begin{array}{l}\text { Percent of } \\
\text { respondents }\end{array}$} \\
\cline { 2 - 3 } & Household & Bathan \\
\hline Age (Years) & 4 & 0 \\
$<24$ & 17 & 21 \\
$25-34$ & 25 & 42 \\
$35-44$ & 25 & 37 \\
$45-54$ & 29 & 0 \\
$55+$ & & \\
Sex & 90 & 100 \\
Male & 10 & 0 \\
Female & &
\end{tabular}

Family size (number)

$\begin{array}{lll}1-5 & 35 & \text { No data } \\ 5+ & 65 & \text { No data }\end{array}$

Educational level

$\begin{array}{lrl}\text { Non formal } & 38 & 21 \\ \text { Up to High School } & 50 & 58 \\ \text { Above High } & 12 & 21\end{array}$

School

$\begin{array}{lll}\text { Occupation } & 75 & 37 \\ \text { Agriculture } & 4 & 16 \\ \text { Service man } & 8 & 37 \\ \text { Business } & 13 & 11 \\ \text { Fulltime farmers } & & \end{array}$

Land area

\begin{tabular}{lll} 
Own & 5 & 5 \\
Leased land & 5 & 15 \\
Public land & 90 & 80 \\
\hline
\end{tabular}

\section{Purposes of buffalo farming}

It was found that $50 \%$ of the household farmers were maintained buffalo farms for both selfemployment and improved livelihood, 20\% for solely milk production, $20 \%$ for solely selfemployment, $18 \%$ for improved livelihood and $5 \%$ for an additional income by producing milk and meat. However, only less than $5 \%$ farmers used their buffaloes for draft purposes mainly to carry the homestead goods along with milk production (Figure 1). Besides, in bathan farming, buffaloes were raised for mostly meat production in which, milk yield was considered as an extra income.

Figure 1. Purposes of rearing of buffalo in household farming

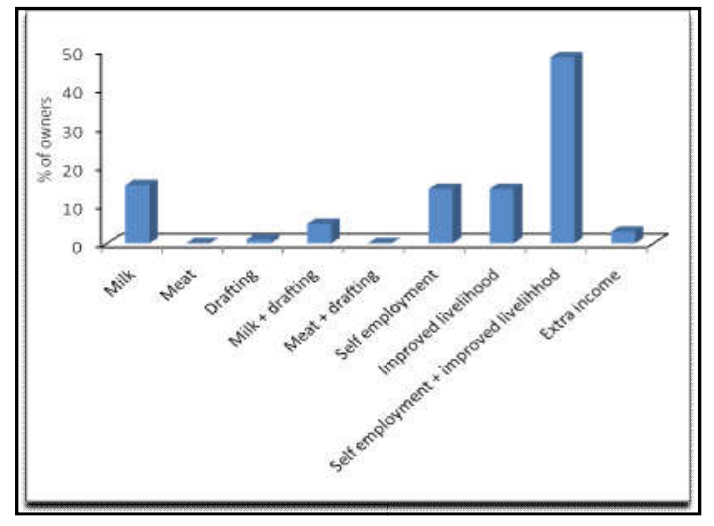

\section{Herd size and type of animal}

The distribution of buffaloes between household and bathan farming systems were presented in Table 2. In the household farming, the average herd size was less than three and it was about $82 \%$ of total respondents. Consequently, $62 \%$ of the total respondents had 51 to 200 animals in bathan farming. In household farming, farmers mainly reared female animals and only $1 \%$ buffalo bull. On the other hand, in bathan farming, $70 \%$ buffaloes were female and the remaining $30 \%$ was male dominantly growing bull and bullock. Among the total female animals, the ratios between milch and dry buffalo were about $2: 1$ and heifer and adult cow $1: 1$ in both household and bathan farming. However, the number of breeding bull in the herd was a very few in number (about 1\%) both in household and bathan farming.

\section{Housing}

In both household and bathan farming, animals were kept normally in open air place throughout the year. In the household system, dairy buffaloes were kept under semi-intensive system in the wet season and kept their animals outside their home only for night. Only $15 \%$ farmers provided shed having only roof but no concrete floor. In bathan farming, buffaloes were raised under extensive management system in the open 


\section{Buffalo milk production in Bangladesh}

areas and provided no housing facilities (data not shown due to unavailable to the farmers).

Table 2. Herd size and type of buffalo

\begin{tabular}{|c|c|}
\hline Parameters & $\begin{array}{l}\text { Percent of } \\
\text { respondents }\end{array}$ \\
\hline \multicolumn{2}{|c|}{ Herd size (number) } \\
\hline \multicolumn{2}{|c|}{ a) Household system } \\
\hline $1-3$ & 82 \\
\hline $4-7$ & 15 \\
\hline $8-10$ & 3 \\
\hline \multicolumn{2}{|l|}{ b) Bathan } \\
\hline$<50$ & 11 \\
\hline $51-100$ & 37 \\
\hline $101-200$ & 25 \\
\hline $201-500$ & 11 \\
\hline$>500$ & 16 \\
\hline \\
\hline \multicolumn{2}{|c|}{ a) Household } \\
\hline \multicolumn{2}{|l|}{ Adult } \\
\hline \multicolumn{2}{|l|}{ Male (Bull) } \\
\hline Female & 1 \\
\hline Growing Calf & 99 \\
\hline \multicolumn{2}{|l|}{ Male } \\
\hline Female & 3 \\
\hline b) Bathan & 97 \\
\hline \multicolumn{2}{|l|}{ Adult } \\
\hline \multicolumn{2}{|l|}{ Male (Bull) } \\
\hline Female & 30 \\
\hline Growing Calf & 70 \\
\hline \multicolumn{2}{|l|}{ Male } \\
\hline \multicolumn{2}{|l|}{ Female } \\
\hline & 0 \\
\hline & 100 \\
\hline
\end{tabular}

\section{Feeds and Feeding}

Feeds and feeding of buffaloes in both farming systems were presented in Table 3. Farmers practiced in both, household (87\%) and bathan (90\%) farming depend on feeding animals at public land. Only few farmers have their own or leased land to feed their animals (Table 3). In the household farming, after morning milking, buffaloes were allowed to graze in fallow or road side land up to evening that covers approximately 8-9 hours per day. From the evening to next morning, animals were tied up in homestead and they were offered mainly rice straw with little concentrate mixtures (wheat bran, rice bran, rice polish etc.). However, in bathan farming, buffaloes were raised in the open grazing area throughout the year. Except calves, all buffaloes (adult and growing heifers) were allowed to graze freely in the public bathan land. In the evening, calves were enclaved in an area locally called "kella" to protect from wild animals. In the bathan, different local grasses are available for animal grazing. During the scarcity of feed in bathan areas, some farmers transferred their buffaloes from bathan to their homestead area and grazed their animals in fallow land this period (January to March/April mainly the dry season). Any extra feed was not provided to buffalo in the bathan farming. Buffaloes were allowed to wallow in the river, canal and big pond excavated by 4-5 farmers jointly. In both of the farming scenarios (household and bathan), buffaloes were managed by the farmers himself or his family members or hired labour (3\%) but animals were never given balanced ration during the year.

Table 3. Feeds and feeding of buffalo

\begin{tabular}{|c|c|c|}
\hline \multirow[t]{2}{*}{ Parameters } & \multicolumn{2}{|c|}{$\begin{array}{l}\text { Percent of } \\
\text { respondents }\end{array}$} \\
\hline & Household & Bathan \\
\hline \multicolumn{3}{|l|}{ Sources of feed } \\
\hline Own land & 8 & 5 \\
\hline Public land & 87 & 90 \\
\hline Leased land & 5 & 5 \\
\hline \multicolumn{3}{|l|}{ Improved feed } \\
\hline Mixed feed & No data & No data \\
\hline Feed store & No data & No data \\
\hline \multicolumn{3}{|l|}{ Feeding system } \\
\hline Grazing in public land & 12 & 100 \\
\hline $\begin{array}{l}\text { Grazing in public land } \\
\text { and cereal grain }\end{array}$ & 88 & 0 \\
\hline $\begin{array}{l}\text { Grazing in public land } \\
\text { and rice gruel }\end{array}$ & 0 & 0 \\
\hline
\end{tabular}

\section{Reproductive characteristics}

The reproductive characteristics of buffaloes were presented in Table 4. Most of the respondents 
reported that the average age at first heat was between 39 and 40 months in both household and bathan farming. However, it was also observed that the average service per conception, gestation length, calving interval, and post partum heat period in both household and bathan farming were found 1.9 and 2.1, 310 and 315 days 390 and 420 days and 125 and 130 days, respectively. The natural mating system was practiced in both the system of farming. Artificial Insemination (AI) was not yet practiced commercially in Bangladesh but sometimes Government and some private enterprise like Lal Teer Livestock Limited were tried to apply AI techniques through different projects.

However, it was observed that bull and cow ratio were very low in both the systems which reflects lower pregnancy rate in reproductive characteristics of buffalo farming which might be one of the reason not to rear buffalo. This is might be due to unavailability of technical knowledge on buffalo reproduction.

Table 4. Reproductive characteristics of buffalo

\begin{tabular}{|c|c|c|}
\hline \multirow[t]{2}{*}{ Parameters } & \multicolumn{2}{|c|}{$\begin{array}{c}\text { Percent of } \\
\text { respondents }\end{array}$} \\
\hline & $\begin{array}{c}\text { House } \\
\text { hold }\end{array}$ & Bathan \\
\hline Age at first heat months) & 37 & 38 \\
\hline \multicolumn{3}{|l|}{ Service per conception (no) } \\
\hline Gestation length (days) & 1.9 & 2.1 \\
\hline \multicolumn{3}{|l|}{ Calving interval (days) } \\
\hline Post partum heat period (days) & 310 & 315 \\
\hline Total lactation length (days) & 390 & 420 \\
\hline Total milk yield/animal (liters) & 125 & 130 \\
\hline \multicolumn{3}{|l|}{ Mating of buffalo } \\
\hline Natural mating & 95 & 99 \\
\hline Artificial insemination & 5 & No data \\
\hline
\end{tabular}

\section{Milk production and milk marketing}

The milk production characteristics and it sale status were presented in Table 5 . The average total milk yield and lactation length was found 799 and 435 liters in 270 and 215 days in household and bathan farming, respectively which showed that total milk yield in buffalo was very low. About $67 \%$ of the farmers milked their animal twice a day (morning and evening) and $33 \%$ of farmers milked their animals once (morning) in the household farming system. In the bathan farming milking was not done until the calves become strong enough which took sometimes up to two months. In contrast, about $87 \%$ of farmers milked their animals once (morning) and only $13 \%$ of farmers milked their animals twice in bathan farming.

Table 5. Milk production and marketing characteristics of buffalo

\begin{tabular}{|c|c|c|}
\hline \multirow[t]{2}{*}{ Parameters } & \multicolumn{2}{|c|}{$\begin{array}{l}\text { Percent of } \\
\text { respondents }\end{array}$} \\
\hline & $\begin{array}{l}\text { House } \\
\text { hold }\end{array}$ & Bathan \\
\hline \multicolumn{3}{|l|}{ Milk production } \\
\hline Milking once in a day & 33 & 87 \\
\hline Milking twice in a day & 67 & 13 \\
\hline \multicolumn{3}{|l|}{ Milk yield/animal/day (Litre) } \\
\hline One to up to two & 20 & 74 \\
\hline Two to up to five & 38 & 26 \\
\hline Five and above & 42 & 0 \\
\hline \multicolumn{3}{|l|}{ Milk marketing channel } \\
\hline Through middle men & 17 & 58 \\
\hline Farmer to milk processor & 17 & 37 \\
\hline $\begin{array}{l}\text { Farmer sale at local } \\
\text { market }\end{array}$ & 13 & 5 \\
\hline $\begin{array}{l}\text { Family consumption and } \\
\text { sale at local market }\end{array}$ & 53 & No data \\
\hline
\end{tabular}

The average daily milk yield was 3 liters in household farming (80\%) whereas it was 1-2 liters in bathan farming (74\%). There was no record keeping system about milk yield for individual animal in bathan. However, total daily milk yield of all buffaloes in a bathan of coastal area was measured by a local measuring system on a bamboo pot to calculate total monthly milk yield for selling to the local agents. In the household farming, it was found that farmers sold their milk in different ways. Seventeen percent farmers sold their milk through middlemen (goala), 17\% of sold directly to milk processors, 


\section{Buffalo milk production in Bangladesh}

$13 \%$ of farmers sold directly at local market and the majority $(50 \%)$ of farmers used the milk for family consumption and a very little amout sold at local market. Whereas in the bathan farming, $58 \%, 37 \%$ and $5 \%$ of famers sold their milk through middleman (goala), directly to processor and directly at local market, respectively.

\section{Discussion}

\section{Characteristics of the farmers}

Ali et al. (2000) found that the highest percentage $(40 \%)$ of farmers had agriculture as principal occupation. Whereas Rahman (1996) told that only $19 \%$ farmers had taken dairying as main business and $81 \%$ as side business.

\section{Purposes of buffalo farming}

In the present study, it was found that the farmers raised buffalo for milk production to improve the family livelihood and selfemployment in the household farming. In this survey study, it was found that most of the buffalo farmers were poor and they have no capital to invest more money to either in buffalo or cattle farming at a commercial level. Furthermore, they are smallholders and do not own enough land for involvement in agricultural activities to improve their livelihood. But a specific report in household system was not available. On the other hand, it was found that in bathan farming, the purposes of buffalo rising were for meat production, and milk was the secondary purpose. Though the quality of buffalo meat was not considered by the Bangladeshi consumers as most of the buffalo is slaughtered at an old age when these animals are neither good for draft power or milk production and thus meat quality is very bad and some times, buffalo meat is found little salty taste. It is because the animals are slaughtered just bringing from saline zone. However, the specific reason for buffalo rearing for meat purpose in bathan zone is due to very low milk production of buffalo raised in bathan, compare to household farming. It was also found that the livelihood improvement and self-employment, income generation and food security was the main purpose of bathan farming.

\section{Herd size and type of animal}

It was observed from the data that there is a variation between two systems i.e. household, non-saline zone system and Bathan, saline zone system in the buffalo number per holding of the country. In the household farming (non-saline zone), number of buffalo per household was 1-3 and in bathan farming (saline zone) the number of buffalo per household was 51-500. In this study, number of buffalo per household was higher than the census report and similar to that of Faruque and Amin (1994). The variability in the buffalo number per household may be fact that the utility of buffalo i.e. dairy, meat and draft purposes. The farmers raised dairy buffaloes had calves and heifers in addition to milch buffaloes whereas farmers kept buffaloes for draft purpose had a pair of buffalo of either male or female. From this study, it reveals that there is an acute shortage of male buffalo in the bathan farming which causes lower pregnancy rate and reduce benefit from buffalo rearing. The reason is not clear but may be unavailability of good quality bulls like Murrah, other Mediterranean improved breeds and etc or the absence of breed development program in Bangladesh or less interest to rear of male buffalo due to higher market price of live animal or absence of better feeding and management problems in both household and bathan farming.

Buffalo was not considered as potential milk animals in Bangladesh and especially dairy buffalo information was not available. This might be due to lower milk production of indigenous buffalo of Bangladesh and also may be the unconsciousness of the farmers and not understanding on milk production as a 
commercial level. The Government did not take any initiatives to improve buffalo and no political and financial support provided like cattle. However, some reports published about the management and production system of dairy buffalo of other countries. Mudgal (1989) reported the semi-intensive management system of dairy buffaloes in the densely populated human settlement in India and Pakistan. Ranawana (1989) reported the intensive management system of dairy buffaloes in the coastal area of Sri-Lanka.

\section{Feeds and feeding}

It is known that the main cost in livestock production is in feeds and it accounts more than $70 \%$ of total production cost. It was found in the survey study that most of the farmers in both of household and bathan farming depend to feed their animals on public land (87 and 90\%, respectively). In bathan (saline zone) farming, only few farmers, who have small herd (below 50) used their own land having natural grass for feeding their animals (5-10\% only) during dry season (February to April) by moving their animals from bathan to own land. It was also observed that in household farming, rice field (after paddy harvest) used as grazing land of buffaloes for 3 to 4 months during the dry seasons (February to April) and rattan (after harvesting paddy) is the main feed sources for the buffaloes and thus animals were suffered seriously for feed shortage.

In both of the farming (household and bathan) farmers are not aware about nutrition requirement of buffaloes and they do not provide any concentrate or mixed feed which causes nutrient deficiency. Feeding of balanced diet of buffalo was not studied in Bangladesh. However, a few researches was conducted on buffalo feeding with urea-molasses straw and concentrate mixture in the semi-extensive farming system and there was no significant effect on the milk yield for buffaloes producing 10 liters or less milk per day (Rai and Agarwala, 1991 and Chauhan et al., 1995).

\section{Reproductive characteristics}

It was found that the age of first heat observed at 39 and 40 months in household and bathan farming, respectively. Nahar et al., (2012) reported the similar results of age of first heat in Mymensingh and Laximpur district. It was reported (Mudgal, 1999) that the age at first calving for Nili-Ravi buffaloes ranges from 30-54 months and for Khundi buffaloes ranges from 4857 months.

\section{Milk production and milk marketing characteristics}

The total milk yield per lactation and lactation period varied between the two systems due to management systems and genotypes of buffaloes. The buffalo raised under household (semi-intensive system) produced higher milk than those raised under bathan (extensive system) which results household farming is more attractive as it gives milk and meat both. The lactation yield in the household farming and bathan farming were 799 and 435 liters, respectively which are much lower than the NiliRavi buffaloes reported by Mudgal (1989), Khan (1995), and ICAR (2000). This result of this study coincide with the result of Faruque et al., (1990), who also reported that the lactation yield was $712 \mathrm{~kg}$ for buffaloes of Mymensingh district. Faruque and Amin (1995) reported that the lactation yield of 280 liters for indigenous buffalo in Khulna region and Hussen (1990) found a lactation yield of 830 liters for buffaloes in Tangail district. It could be concluded from the discussion that the possible important factors is quality of breed/genotype for lower milk production along with other factors. 


\section{Buffalo milk production in Bangladesh}

In household farming, most (approximately 50\%) of farmers used buffalo milk for family consumption and partially sold at local market. About $34 \%$ of farmers sold milk through middlemen and milk processor companies. It could be demonstrated from this study that farmers raised buffalo for drinking milk for family members although about half of the farmers sold milk to maintain their family expenditure.

In bathan farming, farmers sold their whole milk at their bathan area through middlemen where fat content of milk is not considered as a factor and sometimes farmers could not sale their milk at proper price due to the lack of proper transport infrastructure and thus sold at localized processors for making yogurt and local sweets which patch less price than actual price. Family consumption of milk was not reported in bathan farming as in household farming. This could be due to long distance of bathan areas from their homestead and transporting milk from bathan to home was not possible.

\section{Conclusion}

1. Dairy buffaloes belong to the small-holder farmers tending 1 to 3 head of buffaloes per household.

2. Buffaloes are raised under semi-intensive or extensive management system depending upon the region and these buffalo rearing knowledge have acquired from their ancestors from long age practiced. No attempts were made to improve the buffalo breeds, production technology and management technique.

3. The milk production of Bangladeshi indigenous river type buffalo is much lower as compared to crossbred or improved breeds of buffalo due to absence of quality genotype and other relevant management.

4. The feeding system is still in backyard and buffaloes are suffering from lack of balanced ration or feed as they required. In many cases they were treated almost like semi-wild animal.

\section{References}

Ali, MH, M.A.S. Khan, M.N. Islam, M.K.I. Khan, M.M. Rashid and M.J. Khatun, 2000. Comnparative performance of study on the crossbreds and indigenous cows under smallholder dairy farming. Pak. J. Bio. Sci. 3:795-798.

BBS (Bangladesh Bureau of Statistics), 2008. The Bangladesh census of Agriculture and Livestock-1996. Vol. 1, Ministry of Planning, Government of Bangladesh, Dhaka.

Chauhan, T.R., S.S. Dahiya and D.S. Punia. 1995. Effect of supplementing urea-molasses block containing partly degradable proteins on nutrient utilization in lactating buffaloes with oat silage as basal roughage. Buffalo J. $11(3): 249-256$

FAO. 2010. 2008 Production Yearbook.

FAO (Food and Agricultural Organization). 2009. The State of Food and Agriculture.

Faruque, M.O. and M.R. Amin. 1994. Indigenous buffalo in coastal area of Bangladesh. Distribution, pattern and genotypes. Bangladesh J. Training and Development. 7(1): 83-85.

Faruque, M.O. and M.R. Amin. 1995. Indigenous buffalo in coastal area of Bangladesh: Part II. Productivity of indigenous buffaloes in the South Western coastal area. Bangladesh J. Training and Development. 8(1\&2): 138-140.

Faruque, M.O., M.A. Hasanath and N.U. Siddique. 1990. Present status and productivity of buffaloes in Bangladesh raised by the small farmers. Asian-Aust. J. Anim. Sci. 3(4): 287-292.

Ghaffar, A., M.I. Khan, M.A. Mirza and W.H. Prizada. 1991. Effect of year and calving season on some traits of economic importance in Nili-Ravi buffaloes. Pakistan J. Agricult. Res. 12: 217

Huque, Q.M.E., S.K. Fouzder and R. Islam. 2010. Buffalo production system Bangladesh and its economic return based on input-output. Res. Vet. 21 (Sup. 1): 1009-1012. 
Hussen, M.S. 1990. Performance of indigenous buffaloes in Tangail district. M.Sc. Thesis. Bangladesh Agric. Univ.

ICAR- International Committee for Animal Recording. 2000. Yearly inquiry on the situation of milk recording in buffalo. Rome, Italy.

Khan, M.S. 1995. Genetic potential of buffaloes raised under farm condition in Bangladesh. M.S. Thesis, Bangladesh Agricultural University, Mymensingh.

Kumar, R. and R. Singh. 2010. Buffalo production system in India. Rev. Vet. 21 (Sup. 1): 3237.

Mudgal, V.D. 1989. The role of riverine buffaloes in small farm systems in Asia. Proc. Symp. Buffalo Genotypes for small Farms in Asia Univ. Pertinian, Malaysia. 1-9.

Mudgal, V.D. 1999. Milking buffalo. In Smallholder Dairying in the Tropics, International Livestock Research Institute, Chapter six.
Nahar, T.N., M.F. Afroz and J. Fatema. 2012. Characterization of buffalo genetic resources in the selected district of Bangladesh. Annu. Res. Rev. Workshop, Bangladesh Lives. Res. Inst. 24-25 June, 2012: 60-61.

PPRC (Power and Participation Research Centre). 2011. URBAN Bangladesh.

Rahman, M.M., 1996. A study on the present status of private small dairy farms in Dhaka Metropolitan City. M.Sc. Thesis, Department of Dairy Sci., Bangladesh Agricultural University, Mymensingh.

Rai, S.N. and S.K. Agarwala. 1991. Effect of substitution of green fodder with ammoniated straw on nutrient utilization and milk production in Murrah buffaloes. Buffalo J. 7(1): 51-61.

Ranawana, S.S.E. 1989. Water buffaloes in SriLanka. Proc. Symp. Buffalo Genotypes for small Farms in Asia Univ. Pertinian, Malaysia. 31-38.

SAARC (South Asian Association for Regional Cooperation) Statistical Data Book. 2009. 